\title{
Radon in houses of Kowary - Sudety Mountains, Poland
}

\begin{abstract}
The presence of uranium makes the Kowary area characterized by an increased concentration of radon in the air and the living houses. Measurements of periodic radon concentrations in dwellings of Kowary were carried out three times in the last 20 years. It can be observed that 20 years ago level of radon concentrations in houses of Kowary were lower than today. Measurements carried out in Kowary over 20 years have shown that residents are exposed to radon concentrations, which often exceed $300 \mathrm{~Bq} \cdot \mathrm{m}^{-3}-$ a reference level recommended by the European Union. The present geometric mean of radon concentration in houses of Kowary $\left(260 \mathrm{~Bq} \cdot \mathrm{m}^{-3}\right)$ exceeds the geometric mean of radon concentration of buildings in the rest of Poland $\left(142 \mathrm{~Bq} \cdot \mathrm{m}^{-3}\right)$.
\end{abstract}

Keywords: Kowary $\bullet$ Radon $\bullet$ Houses $\bullet$ Annual concentration

\section{J. Olszewski ${ }^{\bowtie}$, K. Walczak}

Department of Radiation Protection

Nofer Institute of Occupational Medicine

Św. Teresy 8, 91-348 Łódź, Poland

E-mail: jerzy.olszewski@imp.lodz.pl

Received: 6 December 2019

Accepted: 22 January 2020

\section{Introduction}

The radioactive elements abounding in the natural environment are the reason that the whole human population is exposed to radiation. Atmospheric radon concentration in Poland remains at $6.5 \mathrm{~Bq} \cdot \mathrm{m}^{-3}$ $[1,2]$, but in closed spaces, where radon tends to accumulate, the concentrations may be many times higher.

Ionizing radiation is known as a carcinogenic agent, and radon has been classified as Class I carcinogen by the International Agency for Research on Cancer (IARC) [3]. As radon is soluble in water and also as a gas is easily released from water, it can easily migrates in the atmosphere. Thus, high radon concentrations may occur in various places, such as living flats, cellars, caves, and mines. The issue of radon pollution as a social problem has found its expression in European Directive No. 2013/59/Euratom of 5 December 2013, which provides that radon should be included in the radiological protection system [4]. The radon problem is also included in the Polish Atomic Law [5].

Kowary city is located between the Rudawy Janowickie and the Giant Mountains at the Jedlica River valley. The intensive development of the Kowarian industry took place in the nineteenth and twentieth centuries. Then intensified mining of iron ores, fluorite, zinc-lead ores, silver, copper, and uranium took place. The presence of uranium makes the Kowary area characterized by an increased concentration of radon in the air and the living houses. 


\section{Method}

Measurements of periodic radon concentrations in dwellings of Kowary were carried out three times by the employees of the Nofer Institute of Occupational Medicine, the first time in 1995, the second time in 2000-2001, and the third time in 2015-2016 ${ }^{1}$. The measurements were conducted in four series quarterly in a year (in some cases one-quarter measurement). To unify the results from quarterly and annual measurements, the correction factors for the determination of annual average radon concentration in dwellings resulting from seasonal variability of indoor radon were used [6]. Dosimeters were placed at the ground floor rooms of buildings, in quantity from one to five pieces depending on the size of the dwelling. Low-rise buildings dominate in Kowary. Measurements were performed only in rooms located on the ground floor, mostly in one- or two-story houses. Measurements in higher buildings were also performed (measurements conducted at the ground floors).

Mean long-term radon concentrations measurements were conducted using close type NRPB passive dosimeter with a CR-39 track detector (or Tastrak). NRPB-type passive radon dosimeter is made of plastic [7]. It consists of two parts. Dimensions of the dosimetric cassette are diameter $5.5 \mathrm{~cm}$ and thickness $2 \mathrm{~cm}$. Track detector CR-39 is located inside the dosimetric cassette. An important design feature of the dosimeter NRPB-type is that after it is closed, only radon can diffuse through microcavities to the inside. Thus, radon concentration inside the dosimetric chamber reaches a value equal to that existing in the ambient air, regardless of the concentration of radon daughters in the air. When precise measurement time is known, one can calculate the average concentration of radon in the air during that period. Therefore, dosimeter NRPB-type is an instrument to determine the radon exposure. Dosimeter NRPB-type is shown in Fig. 1. Basic technical information ${ }^{2}$ : Lower detection threshold: $20 \mathrm{kBq} \cdot \mathrm{h} \cdot \mathrm{m}^{-3}$; upper detection threshold: $1 \mathrm{MBq} \cdot \mathrm{h} \cdot \mathrm{m}^{-3}$; precision of measurement: $15 \%$; surface analysed: $192 \mathrm{~mm}^{2}$; own background of the detector: $1.1 \mathrm{tr} \cdot \mathrm{mm}^{-2}$.

Before starting the measurements, a new batch of detectors was purchased. Each batch of these detectors was calibrated in the Institute of Occupational Medicine (IMP) in a radon chamber with a volume of $2 \mathrm{~m}^{3}$. Furthermore, the correctness of detector's indications used by the IMP is regularly verified

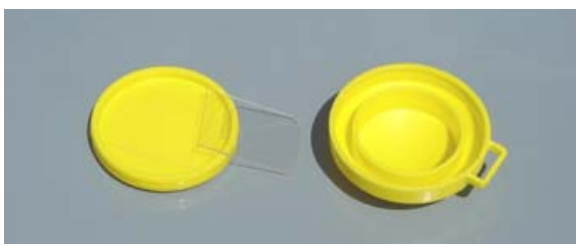

Fig. 1. Opened NRPB-type dosimetric cassette with a CR-39 detector.

1) The research was carried out as part of the IMP 16.13 project and funded by the Nofer Institute of Occupational Medicine: "Verification of radon hazard in Kowary".

2) For detectors used in 2015-2016. by the international and national interlaboratory comparisons.

The analysis of track detectors is conducted using an image analysis system by the IMAL company [8] available in the Nofer Institute of Occupational Medicine in Łódź.

As a result of the analysis, the density of traces per $\mathrm{mm}^{2}$ is obtained, which in turn is used to calculate the exposure that the detector was subjected to.

\section{Results}

The results of measurements conducted in 1995 were the average annual radon concentration of $150 \mathrm{~Bq} \cdot \mathrm{m}^{-3}$ with a standard deviation of the mean equal $20 \mathrm{~Bq} \cdot \mathrm{m}^{-3}$, and the maximum reached was $560 \mathrm{~Bq} \cdot \mathrm{m}^{-3}$. In the years 2000-2001, the average annual radon concentration was $350 \pm 16 \mathrm{~Bq} \cdot \mathrm{m}^{-3}$, and the maximum reached was $650 \mathrm{~Bq} \cdot \mathrm{m}^{-3}$. The average for recent measurements (2015-2016) was $390 \pm 42$ $\mathrm{Bq} \cdot \mathrm{m}^{-3}$, and the maximum of radon concentration measured was $2500 \mathrm{~Bq} \cdot \mathrm{m}^{-3}$. The geometric mean of radon concentration in 2015-2016 was $260 \mathrm{~Bq} \cdot \mathrm{m}^{-3}$. Figure 2 shows the distributions of average quarterly radon concentrations.

In most houses, the measurements were carried out two times over 20 years. In a few houses, the measurements were carried out three times over 20 years. Figure 3 shows a comparison of the aver-

a 1995

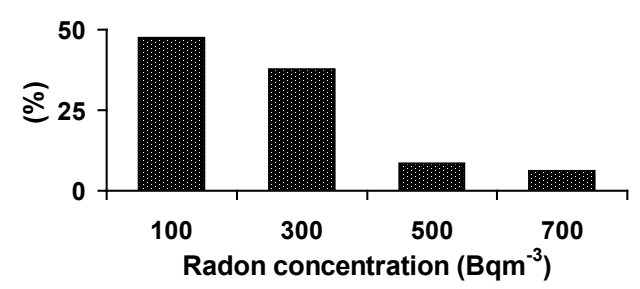

$b$

$2000-2001$

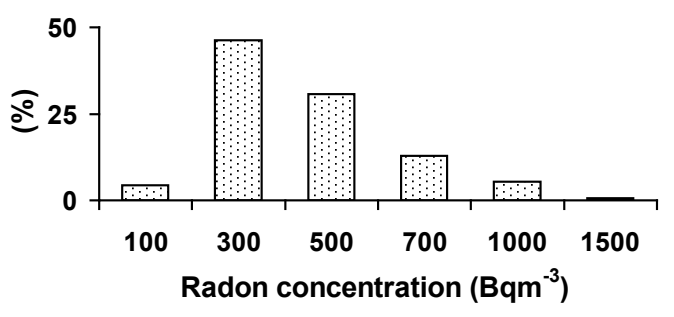

2015 - 2016

c

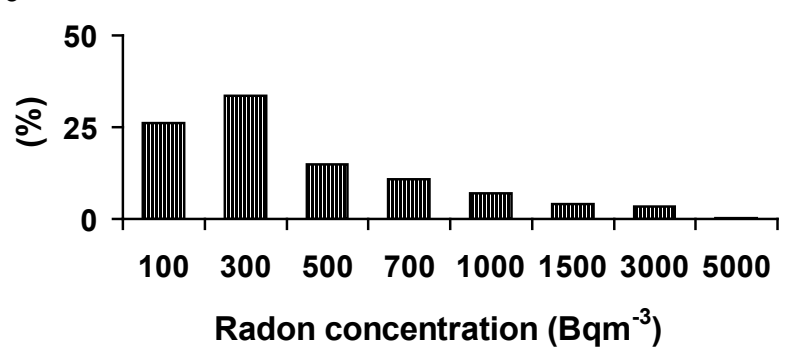

Fig. 2. Average quarterly radon concentrations measured in houses in Kowary in 1995 (a), 2000-2001 (b), and 2015-2016 (c). 


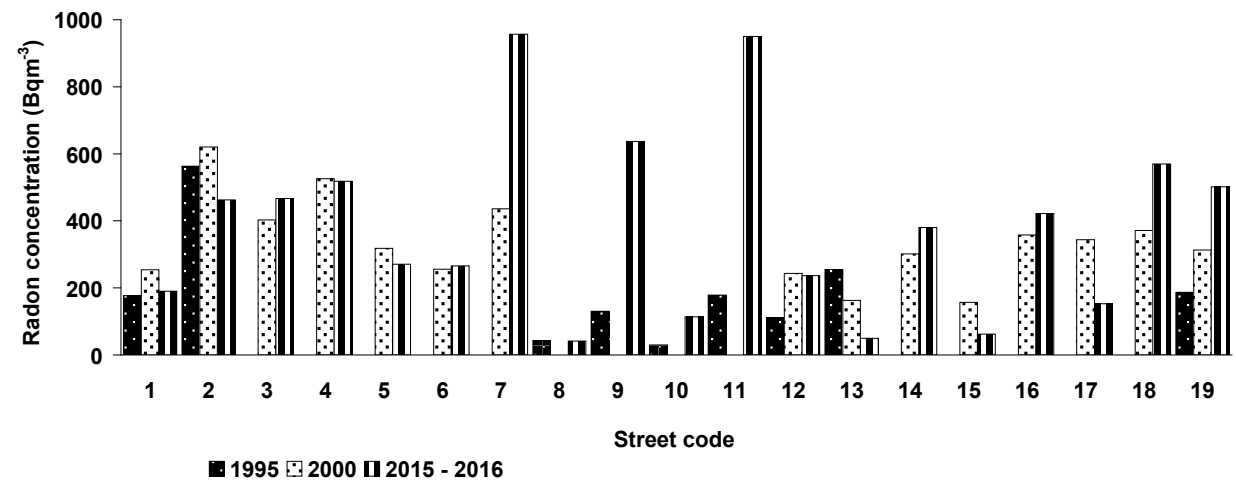

Fig. 3. Comparison of average annual radon concentration measurements made two or three times in some apartments in Kowary. Legend: Kowary north: 1-7 Wojska Polskiego St.; Kowary centre: 8 - Sienkiewicza St., 9 - Jagiellońska St., 10 - Kowalska St., 11 - 1 Maja St.; Kowary south: 12-15 Wiejska St., 16-19 Podgórze St.

age annual radon concentrations calculated from quarterly measurements in a given apartment.

\section{Conclusion}

Measurements carried out in Kowary over 20 years have shown that residents are exposed in their houses to radon concentrations, which often exceed $300 \mathrm{~Bq} \cdot \mathrm{m}^{-3}-$ a reference level recommended by the European Union.

It can be seen in Fig. 3 that in some flats (in which radon concentration was measured three times), the annual radon concentration has a tendency to increase during the observed years. A similar conclusion can be drawn by comparing the charts (Fig. 2) - 20 years ago radon concentrations in houses of Kowary were lower than today. It can be suspected that this is due to the replacement of windows to a new, airtight, and thus greater accumulation of radon in apartments occurs when comparing with previous years.

It will be interesting to compare the results of radon measurements in Kowary with the rest of Poland. In 2008-2009, annual measurements of radon concentrations were carried out in 129 buildings throughout the country using CR-39 detectors ${ }^{3)}$. The distribution of mean annual values of radon activity concentration in residential buildings in the areas of almost all main tectonic units of Poland seems to have a log-normal character. The highest maximum values of mean annual radon concentration were recorded in buildings situated in the Sudety Mts. (reach up to $845 \mathrm{~Bq} \cdot \mathrm{m}^{-3}$ ) [9]. Based on the information received in the research, the geometric mean of radon concentration for all buildings in Poland is $142 \mathrm{~Bq} \cdot \mathrm{m}^{-3}$. Present geometric mean of radon concentration in dwellings of Kowary exceeds almost twice the geometric mean of radon concentration in buildings of Poland and reaches $260 \mathrm{~Bq} \cdot \mathrm{m}^{-3}$.

In the light of the new law [5], it seems that the level of radon concentration occurring in Kowarian buildings may be a problem for the city authorities.

\footnotetext{
3) The research was conducted as a part of Project No. N506 112733 and was financed by the Ministry of Science and Higher Education of Poland, in 2007-2009.
}

\section{ORCID}

J. Olszewski (1) http://orcid.org/0000-0002-7565-4629

\section{References}

1. Central Laboratory for Radiological Protection. (1988). Radiation atlas of Poland. Warszawa: CLOR. (in Polish).

2. Podstawczyńska, A. (2013). Meteorological factors of radon concentration in the near ground air layer in an urban and rural environment. Łódź: Wydawnictwo Uniwersytetu Łódzkiego. (in Polish).

3. International Agency for Research on Cancer. (1988). Manmade mineral fibres and radon. (IARC Monographs on the Evaluation of Carcinogenic Risks to Humans, Vol. 43). Lyon, France: IARC.

4. European Union. (2013). Council Directive 2013/59/ Euratom of 5 December 2013 laying down basic safety standards for protection against the dangers arising from exposure to ionising radiation, and repealing Directives 89/618/Euratom, 90/641/Euratom, 96/29/ Euratom, 97/43/Euratom and 2003/122/Euratom. Official Journal of the European Union, OJ L13, 17.1.2014, 1-73. https://eur-lex.europa.eu/legalcontent/EN/TXT/?uri=OJ:L:2014:013:TOC.

5. Polish Atomic Law. (2019). Law of June 13, 2019 amending the Atomic Law and the Act on fire protection. Dz.U., 2019, item 1593. (in Polish).

6. Kozak, K., Mazur, J., Kozłowska, B., Karpińska, M., Przylibski, T. A., Mamont-Cieśla, K., Grządziel, D., Stawarz, O., Wysocka, M., Dorda, J., Żebrowski, A., Olszewski, J., Hovhannisyan, H., Dohojda, M., Kapała, J., Chmielewska, I., Kłos, B., Jankowski, J., Mnich, S., \& Kołodziej, R. (2011). Correction factors for determination of annual average radon concentration in dwellings of Poland resulting from seasonal variability of indoor radon. Appl. Radiat. Isot., 69(10), 1459-1465. DOI: 10.1016/j.apradiso.2011.05.018.

7. Gilvin, P. J., \& Bartlett, D. T. (1988). Performance of a PADC radon dosemeter. Nucl. Tracks Radiat. Meas., 15(1/4), 571-576.

8. Kluszczyński, D., Jankowski, J., Chruścielewski, W., \& Olszewski, J. (1996). The implementation of $a$ new type of dosimeter with a CR-39 detector and 
a laboratory comparison of various measurement techniques used to assess the exposure caused by ${ }^{222} \mathrm{Rn}$ and his daughter decay. Unpublished report of the Nofer Institute of Occupational Medicine. (Theme Report 17.2). Łódź: IMP. (in Polish).

9. Przylibski, T. A., Żebrowski, A., Karpińska, M., Kapała, J., Kozak, K., Mazur, J., Grządziel, D., Ma-
mont-Cieśla, K., Stawarz, O., Kozłowska, B., Kłos, B., Dorda, J., Wysocka, M., Olszewski, J., \& Dohojda, M. (2011). Mean annual (222)Rn concentration in homes located in different geological regions of Poland: first approach to whole country area. J. Environ. Radioact., 102(8), 735-741. 